CLINICAL STUDY

\title{
Association between estrogen and androgen receptor genes and prostate cancer risk
}

Nathalie Nicolaiew ${ }^{2}$, Geraldine Cancel-Tassin ${ }^{1}$, Abdel Rahmene Azzouzi ${ }^{1,4}$, Beatrice Le Grand ${ }^{5}$, Philippe Mangin ${ }^{1,6}$, Luc Cormier ${ }^{1,6}$, Georges Fournier ${ }^{1,7}$, Jean-Pierre Giordanella ${ }^{8}$, Michel Pouchard ${ }^{8}$, Jean-Louis Escary ${ }^{9}$, Antoine Valeri ${ }^{1,7}$ and Olivier Cussenot ${ }^{1,3}$

${ }^{1}$ CeRePP, Hôpital Tenon, 75020 Paris, France, ${ }^{2}$ Faculté de Médecine, Institut Mondor de Médecine Moléculaire (IFR10), Université Paris 12, Créteil F-94010, France, ${ }^{3}$ Assistance Publique-Hôpitaux de Paris, Department of Urology, Tenon Hospital, GHU Est, University Paris VI, Paris, France, ${ }^{4}$ CHU d'Angers, Department of Urology, Angers, France, ${ }^{5}$ Université Paris 5, UFR Biomédicale des Saints-Pères, Paris, France, ${ }^{6} \mathrm{CHU}$ Brabois, Department of Urology, Nancy, France, ${ }^{7}$ Department of Urology, Hopital de la Cavale Blanche, Brest, France, ${ }^{8}$ Centres d'examen de Santé de l'Assurance Maladie, CNAM, Paris, France and ${ }^{9}$ GenOdyssee SA, Evry, France

(Correspondence should be addressed to G Cancel-Tassin who is now at CeRePP, Laboratoire Urologie, Hôpital TENON APHP, Bâtiment Recherche, $5^{e}$ étage, 4 rue de la Chine, 75970 Paris Cedex 20, France; Email: geraldine.cancel-tassin@tnn.aphp.fr)

\begin{abstract}
Objective: Prostate cancer (PC) is one of the principal causes of death among men. Steroid hormones are involved in normal prostate growth and carcinogenesis. The purpose of our study was to investigate the effects on PC risk of polymorphisms from three steroid hormone receptor genes: the androgen $(A R)$, and the $\alpha$ (ESR1) and $\beta$ (ESR2) estrogen receptors.

Design and methods: The study was performed on a Caucasian population of 1045 PC patients and 814 controls. Using a logistic regression model, the different alleles and genotypes from those polymorphisms were analyzed according to case/control status, the tumor aggressiveness, and the age at onset. Results: A significant association between PC risk and the pooled $4 / 5,5 / 6$, and $6 / 6$ genotypes of the GGGA repeat located in the first intron of ESR 1 (odds ratio $(\mathrm{OR})=3.00,95 \% \mathrm{CI}=1.32-6.82, P=0.008$ ) was observed. When we stratified the cases, this association was confined to patients with a Gleason score of $2-4(\mathrm{OR}=8.34,95 \% \mathrm{CI}=2.91-23.91, \mathrm{P}<0.0001)$ or late onset $\mathrm{PC}(\mathrm{OR}=2.91,95 \% \mathrm{CI}=1.22-6.93$, $P=0.016)$. An association between a short $A R C A G$ repeat (less than 17 repeats) was also observed among patients with late onset $\mathrm{PC}(\mathrm{OR}=2.34,95 \% \mathrm{CI}=1.15-4.76, \mathrm{P}=0.019)$.

Conclusions: These findings suggest that the GGGA repeat from ESR1 and the CAG repeat from AR may be associated with risk of late onset PC.
\end{abstract}

European Journal of Endocrinology 160 101-106

\section{Introduction}

Prostate cancer (PC) is one of the major causes of death among men in developed countries (1). The principal risk factors are age, familial history, and ethnicity. Sex steroid hormones like androgens and estrogens are important in PC development. Indeed, evidence supports the hypothesis that exposure to endogenous variations in androgens and estrogens across a man's life span contributes to or may be a causal factor in the development of PC. While androgen deprivation and administration of estrogens are recognized therapies for PC, early exposure to estrogens is suspected to initiate carcinogenesis among different tissues, including the prostate gland. A decrease in the ratio of androgens to estrogens with aging could also be responsible for prostate carcinogenesis.

Growth and differentiation of the prostate are controlled by androgens such as testosterone and $5 \alpha$ dihydrotestosterone. Their effects are mediated through their interaction with the androgen receptor (AR) that is expressed in the prostatic epithelial cells (2). Estrogens could also have an indirect role through repression of the hypothalamic-pituitary-gonadal axis and direct effects on the testis. Estrogens produced by peripheral aromatization of testosterone exert their effects on prostatic tissue by interaction with their receptors, estrogen receptor $\alpha$ (ESR 1$)$, and $\beta$ (ESR2). These receptors are expressed with distinct tissue and cell-specific patterns. In the normal prostate, ESR 1 is only found in stromal cells whereas ESR2 is expressed in the majority of epithelial cells and in some stromal cells (3).

In tumoral tissue, AR expression is observed in primary cancers and during progression to hormone refractory carcinoma. Immunohistological studies have shown a heterogeneous expression pattern of AR in PC (4). ESR1 has been reported to be expressed in both stromal and epithelial cells in prostate tumors (5); however, results are inconsistent among studies with other reports showing only stromal expression (3). By contrast, ESR2 is commonly expressed in the epithelial cells of prostate tumors (3). 
A reduction in ESR2 expression has been observed during carcinogenesis, suggesting a role for this receptor in the maintenance of normal prostate epithelium $(6,7)$. Cancers retaining ESR2 expression seem to be associated with a highly malignant phenotype (8). Decreased expression of the ESR 1 gene has also been found in PC and particularly, in hormone refractory tumors (7).

Moreover, experimental studies performed in rodents have also demonstrated that estrogens through their receptors are potentially carcinogenic in the prostate. In rodents, neonatal estrogenization inhibits prostate growth and function, and promotes the development of dysplastic lesions (9). Experiments with ER-deficient mice have indicated that the effects of neonatal exposure to high doses of estrogens are largely mediated through stromal ESR1, but are not associated with ESR2 (10). Weihua et al. (11) reported that ER $\beta K O$ mice displayed hyperplastic foci and increased expression of the proliferation marker Ki-67 in prostate. By contrast, in another study, no prostatic abnormality was observed in other ER $\beta K O$ mice (12). Estrogens have also been shown to induce prostate tumors in rats when associated with androgens $(13,14)$.

To study the role of estrogen receptors in the risk of PC, we screened the ESR 2 gene for polymorphisms and compared their distribution in PC patients and healthy controls. We also evaluated two previously reported polymorphisms in the ESR 1 and AR genes in a large population. The first polymorphism is the GGGA repeat localized in the first intron of the ESR1 gene, which our group has previously shown to be associated with increased PC risk in a smaller study (15). The second is the highly variable CAG repeat (encoding polyglutamine) which is located in the first exon of the $A R$ gene corresponding to the transactivation domain (16).

\section{Subjects and methods}

\section{Study population}

In this study, 1045 PC cases and 814 controls of Caucasian origin were included. All the participants gave informed consent. The protocol was approved by the Institutional Review Board (IRB) from CCP Ile de France IV (Paris Saint-Louis). Cases were recruited from three French departments of urology (Paris, Nancy, and Brest) and were diagnosed with a histological confirmed adenocarcinoma of the prostate. Aggressiveness of the cancer was based on pathological TNM Classification 2004, Gleason score and PSA level (mean \pm s.D.: $99.36 \mathrm{ng} / \mathrm{ml} \pm 707.43 \mathrm{ng} / \mathrm{ml})$. Subjects ranged from 40 to 98 years of age ( mean $=67$ years).

Controls were selected from men invited to a systematic health screening, under the proposition of the national health insurance, performed in the same geographical areas than the hospitals where the cases were collected. They were checked by digital rectal examination, their prostate specific antigen (PSA) value had to be less than $4 \mathrm{ng} / \mathrm{ml}$, and they could exhibit no signs of prostate carcinoma. Their mean age was 63 years (range 40-92 years).

Genomic DNA was extracted from peripheral blood leukocytes using standard methods.

\section{Detection of polymorphisms in the ESR2 gene}

Specific primers encompassing each coding exon of the human estrogen $\beta$ receptor were designed. Each fragment of the gene was amplified as follows. In a final volume of $25 \mu \mathrm{l}$, $5 \mathrm{ng}$ genomic DNA, $200 \mu \mathrm{M}$ dNTP, $0.02 \mathrm{M} \mathrm{MgSO}_{4}, 0.2 \mu \mathrm{M}$ of each primer, and $0.375 \mathrm{U}$ of Taq Platinum (Gibco) were mixed. To rapidly screen for the presence or absence of polymorphisms, three PCR products either from three patients or three controls were pooled. The pooled samples were then analyzed by DHPLC as described in patent FR-2793262.

\section{Genotyping}

Genotyping of the ESR 2 polymorphisms was done using fluorescence polarization template-direct dye-terminator incorporation technology, as described in (15). The AcycloPrime-FP SNP Detection Kit (Perkin-Elmer Life Sciences Inc., Boston, MA, USA) was used for the extension step. Fluorescence polarization of the two dye terminators was analyzed directly in the final reaction mix with an Analyst fluorescence reader from LJL Biosystems (Boston, MA, USA).

Genotyping was performed as already described in (17) for the CAG repeat from $A R$ and in (15) for the GGGA repeat from ESR1. Briefly, primers encompassing the CAG repeat $\left(5^{\prime}\right.$-tccagaatctgttccagagcgtgc- $3^{\prime}$ and $5^{\prime}$-actgcggctgtgaaggttgctgt- $3^{\prime}$ ) or the GGGA repeat $\left(5^{\prime}\right.$-gcccgctgatgctactgc- $3^{\prime}$ and $5^{\prime}$-tgggtggagagtacgtttttt- $\left.3^{\prime}\right)$ were selected. One primer was fluorescently labeled. For the AR CAG repeat, PCR amplification was carried out in a final volume of $50 \mu \mathrm{l}$, containing $50 \mathrm{ng}$ DNA, $20 \mathrm{pmol}$ of each primer, $100 \mu \mathrm{M}$ each of dNTP, $1.5 \mathrm{mM} \mathrm{MgCl}, 10 \mathrm{mM}$ Tris- $\mathrm{HCl} \mathrm{pH}$ 8.3, $50 \mathrm{mM} \mathrm{KCl}$, and 1 unit Taq DNA polymerase (Applied Biosystems, Foster City, CA, USA), in the following cycling conditions: $10 \mathrm{~min}$ at $94^{\circ} \mathrm{C}$, then 35 cycles of $40 \mathrm{~s}$ at $94{ }^{\circ} \mathrm{C}, 30 \mathrm{~s}$ at $60^{\circ} \mathrm{C}, 30 \mathrm{~s}$ at $72^{\circ} \mathrm{C}$. For the ESR 1 GGGA repeat, PCR was carried out in a final volume of $20 \mu \mathrm{l}$, containing $50 \mathrm{ng}$ genomic DNA, $250 \mu \mathrm{M}$ dNTP, $1 \mu \mathrm{M}$ each primer, 2.5 U Taq Gold (Applied Biosystems), $2.5 \mathrm{mM} \mathrm{MgCl}_{2}$, and $5 \% \mathrm{DMSO}$, in the following cycling conditions: $5 \mathrm{~min}$ at $95^{\circ} \mathrm{C}$, then 35 cycles of $30 \mathrm{~s}$ at $94^{\circ} \mathrm{C}$, $30 \mathrm{~s}$ at $53{ }^{\circ} \mathrm{C}, 30 \mathrm{~s}$ at $72{ }^{\circ} \mathrm{C}$. The final extension step at $72{ }^{\circ} \mathrm{C}$ was extended to $10 \mathrm{~min}$. PCR products were then loaded on 5\% denaturing polyacrylamide gel and detected with an ABI Prism 377 DNA automated sequencer. Genotypes were determined with Genescan Analysis 3.1 software (Applied Biosystems). 


\section{Statistical analysis}

Genotypes of ESR1 and ESR2 were tested for HardyWeinberg equilibrium. The distribution of polymorphisms was tested with a $\chi^{2}$ test or Fisher's exact test. Odds ratios and a 95\% confidence interval $(95 \%$ CI) were calculated with logistic regression with adjustment for age. Statistical analyses were performed using SPSS software version 14.0 (SPSS Inc., Chicago, IL, USA).

\section{Results}

The coding sequence of the ESR2 gene was initially screened for polymorphisms in 96 patients (mean age at diagnosis: 67.9; range 45-86 years) and 96 controls (mean age: 69.2; range 59-86). Eleven polymorphisms were identified (Table 1), four in the coding region (one was already reported: rs1256049), two in introns (one already described: rs944050), and five in the $3^{\prime}$ UTR (three already described: rs4986938, rs928554 and rs28440970). Three of the four polymorphisms located in exons modified the protein sequence: S112Stop, DelN181 and R221G. When we compared the genotype or allele distribution between cases and controls, none of the polymorphisms showed significant association with PC risk (Table 1). Four of them (S112Stop, rs4986938, rs928554, and rs28440970) were further investigated in 290 patients (mean age at diagnosis: 69.2; range 45-98 years) and 290 controls (mean age: 69.8; range 48-92). Their genotype distributions were in agreement with Hardy-Weinberg equilibrium. Again, we noted an absence of association with PC risk (Table 1).

We identified three alleles for the GGGA repeat from the ESR 1 gene corresponding to four, five, or six repeats; the five-repeat allele was the most frequent. The HardyWeinberg equilibrium was respected in the control population. Twenty-three PC cases, but only eight controls had a genotype other than 5/5. A significant association was then observed between the pooled genotypes $4 / 5,5 / 6$, and $6 / 6$ and $\mathrm{PC}$ risk $(\mathrm{OR}=3.00,95 \% \mathrm{CI}=1.32-6.82$, $P=0.008$; Table 2). When the alleles 4 and 6 were pooled, the association was also statistically significant $(\mathrm{OR}=3.65,95 \% \mathrm{CI}=1.73-7.72, P=0.001)$.

The AR CAG repeats from cases ranged from 10 to 34 with a mean length of 21.9 repeats (s.D. 3.04, median $=22$ ). In controls, they ranged from 11 to 34 with a mean length of 22.1 repeats (s.D. 3.03, median $=22$ ). For the statistical analyses, study subjects were considered as having a short CAG repeat allele (less than 17) or a long allele (17 or more) as already performed in a previous study (16). No significant association was observed between this polymorphism and PC risk $(P=0.085$; Table 2$)$.

To study the impact of these polymorphisms on PC aggressiveness, patients were stratified according to Gleason score and divided in four classes: $2-4,5-6,7$, and $8-10$. We found that the association between the

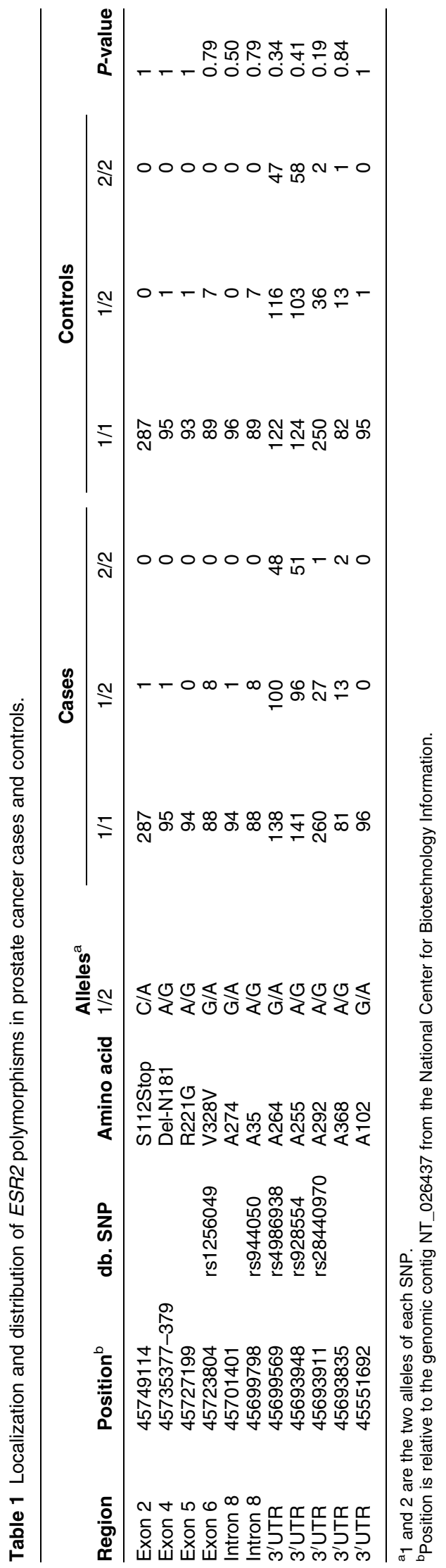

www.eje-online.org 
Table 2 Association between ESR1 and AR polymorphisms and prostate carcinoma risk.

\begin{tabular}{|c|c|c|c|c|c|}
\hline Gene & Genotype or allele & Cases/controls & $\mathrm{OR}^{\mathrm{a}}$ & $95 \% \mathrm{Cl}^{\mathrm{b}}$ & $\boldsymbol{P}$-value \\
\hline \multirow[t]{3}{*}{ ESR1 } & 5/5 Genotype & $550 / 541$ & 1 & & \\
\hline & $\begin{array}{l}\text { 4/5, 5/6, 6/6 Genotype } \\
5 \text { Allele }^{\mathrm{c}}\end{array}$ & $\begin{array}{l}23 / 8 \\
1114 / 1089\end{array}$ & $\begin{array}{l}3.00 \\
1\end{array}$ & $1.32-6.82$ & 0.008 \\
\hline & 4, 6 Allele & $32 / 9$ & 3.65 & $1.73-7.72$ & 0.001 \\
\hline \multirow[t]{2}{*}{$A R$} & $\geq 17$ repeats $^{d}$ & $966 / 757$ & 1 & & \\
\hline & $<17$ repeats & 29/12 & 1.83 & $0.92-3.66$ & 0.085 \\
\hline
\end{tabular}

${ }^{\mathrm{a} O R}$, odds ratio adjusted for age.

${ }^{\mathrm{b}} \mathrm{Cl}$, confidence interval.

${ }^{c} 4,5$, and 6 correspond to the number of GGGA repeat.

$d_{17}$ corresponds to the number of CAG repeat.

pooled genotypes $4 / 5,5 / 6$, and $6 / 6$ of ESR 1 and PC was confined to patients with Gleason score of $2-4(\mathrm{OR}=8.34$, $95 \% \mathrm{CI}=2.91-23.91, P<0.0001$; Table 3 ).

The age at onset of the PC cases was also divided in two classes: early onset if their cancer was diagnosed $\leq 64$ years and late onset if it was diagnosed $>64$ years. The association between the ESR 1 pooled genotypes $(4 / 5,5 / 6$, and 6/6) or AR CAG repeat $<17$ alleles and PC risk was confined to cases with late onset: $\mathrm{OR}=2.91$, $95 \% \mathrm{CI}=1.22-6.93, \mathrm{P}=0.016$ and $\mathrm{OR}=2.34,95 \%$ $\mathrm{CI}=1.15-4.76, P=0.019$ respectively (Table 3 ).

\section{Discussion}

By screening the coding sequence of the ESR2 gene, we identified eleven polymorphisms but did not find any association between those polymorphisms and PC risk.

Table 3 Association between ESR1 and $A R$ polymorphisms and risk of prostate cancer, stratified by Gleason score or by age at onset.

\begin{tabular}{lllll}
\hline Gene & Genotype & OR $^{\mathrm{a}, \mathrm{b}}$ & $\mathbf{9 5 \%} \mathbf{C l}^{\mathrm{c}}$ & $\boldsymbol{P}$-value \\
\hline ESR1 & & & & \\
Gleason score & & & & \\
$2-4$ & $4 / 5,5 / 6,6 / 6^{\mathrm{d}}$ & 8.34 & $2.91-23.91$ & $<0.0001$ \\
$5-6$ & $4 / 5,5 / 6,6 / 6$ & 2.49 & $0.92-6.74$ & 0.07 \\
7 & $4 / 5,5 / 6,6 / 6$ & 1.81 & $0.53-6.13$ & 0.34 \\
$8-10$ & $4 / 5,5 / 6,6 / 6$ & 2.52 & $0.65-9.77$ & 0.18 \\
Onset & & & & \\
$\leq 64$ years & $4 / 5,5 / 6,6 / 6$ & 2.69 & $1.00-7.27$ & 0.051 \\
$>64$ years & $4 / 5,5 / 6,6 / 6$ & 2.91 & $1.22-6.93$ & 0.016 \\
AR & & & & \\
Gleason score & & & & \\
$2-6$ & $<17$ repeats & \\
7 & $<17$ repeats & 1.95 & $0.90-4.21$ & 0.09 \\
$8-10$ & $<17$ repeats & 1.57 & $0.55-3.71$ & 0.46 \\
Onset & & & & 0.45 \\
$\leq 64$ years & $<17$ repeats & 1.19 & $0.47-3.05$ & 0.72 \\
$>64$ years & $<17$ repeats & 2.34 & $1.15-4.76$ & 0.019 \\
\hline
\end{tabular}

${ }^{a} \mathrm{OR}$, odds ratio adjusted for age only for Gleason score.

${ }^{\mathrm{b}}$ For Gleason score or onset, the category of reference is the ESR1 genotype $5 / 5(\mathrm{OR}=1)$ or the $A R$ allele $\geq 17(\mathrm{OR}=1)$.

${ }^{\mathrm{C}} \mathrm{Cl}$, confidence interval.

${ }^{d} 4,5$, and 6 correspond to the number of GGGA repeat

epatients with Gleason score of 2-4 and 5-6 were pooled because the class

Gleason 2-4 included too few patients.

$f_{17}$ corresponds to the number of CAG repeat.
Our results agree with a previous study performed by Thellenberg-Karlsson et al. (18), which analyzed 28 SNPs spanning the entire ESR2 gene in 1415 PC cases and 801 controls. In this study, only one polymorphism (rs29877983) located in the promoter region was significantly associated with $\mathrm{PC}$ risk $(\mathrm{OR}=1.22,95 \%$ $\mathrm{CI}=1.02-1.46)$ and with localized carcinomas $(\mathrm{OR}=$ 1.33 , 95\% CI $=1.08-1.64$ ). Because our study focused on the ESR 2 coding region, this part of the promoter was not analyzed. Together, these results are not in favor of a major role of the ESR2 gene in PC susceptibility. Among the identified exonic polymorphisms, the S112Stop, which leads to a truncated protein, was observed in one of the 288 PC cases and none of the 288 controls. This variant should thus be considered as an infrequent mutation.

We also did not find a significant association between the AR CAG repeat and the risk of PC, even when the cases were stratified according to Gleason score. This is in agreement with other studies including a multiethnic cohort study of 1014 cases (19) and another study of 460 cases (20), which did not observe any association between $A R$ CAG repeats and PC risk. Indeed, results regarding the $A R C A G$ repeat polymorphism and association with PC risk have been very contradictory as reviewed by Simard et al. (21). Several studies have found an association between short CAG repeats $(\leq 20$ or 22) and the risk of PC in Caucasian populations (22, 23) whereas others have reported a reduced risk of PC associated with short alleles $(\leq 22)$ after an analysis of 1461 and 288 cases respectively $(24,25)$. Finally, a meta-analysis of 19 case-control studies comprising a total of 4274 cases and 5275 controls with $79 \%$ of Caucasians concluded that a modest association existed between the shorter repeats $(\leq 21)$ and PC risk $(\mathrm{OR}=$ $1.19,95 \% \mathrm{CI}=1.07-1.31)(26)$.

Nevertheless, when the cases were stratified according to age at onset, we observed a significant association between CAG repeats less than 17 and PC risk among patients with an age at diagnosis above 64 years $(\mathrm{OR}=2.34,95 \% \mathrm{CI}=1.15-4.76, \mathrm{P}<0.019)$. By contrast, Hardy et al. (27) found a positive correlation between CAG repeats $\geq 23$ with increased age at diagnosis. However, this divergent study only included 109 cases and the statistical analysis was based on 
correlations between length of CAG repeats and age at diagnosis. Finally, the association between the AR CAG repeat and PC risk seems to be limited. These contradictory results could be due to the heterogeneity of many factors such as the number of cases, the various ethnicities, the different gravity and age at diagnosis of cases, and the cut-point of CAG repeats.

In this study, we showed that rare alleles consisting of four or six GGGA repeats from the ESR1 gene were significantly associated with $\mathrm{PC}$ risk $(\mathrm{OR}=3.65,95 \%$ $\mathrm{CI}=1.73-7.72, \mathrm{P}<0.001)$. In a previous study including 300 cases and 300 controls, we reported that this ESR 1 GGGA repeat polymorphism was significantly associated with PC risk $(P=0.036)(15)$. Here, in a larger population, we confirmed this result and showed a stronger association among patients with Gleason score of 2-4 $(\mathrm{OR}=8.34,95 \% \mathrm{CI}=2.91-23.91, P<0.0001)$ or with an age at onset of the cancer above 64 years $(\mathrm{OR}=2.91$, 95\% CI $=1.22-6.93, P=0.016)$. These results indicate that this ESR1 polymorphism could be a useful indicator of PC low gravity.

No other study has been performed on the ESR 1 GGGA repeat polymorphism and until now, only a few studies of other ESR1 polymorphisms and PC risk have been undertaken. Two other polymorphisms: PvuII (rs2234693) and XbaI restriction sites (rs9340799), located in the first intron of the ESR 1 gene were studied in different ethnic populations. Modugno et al. (28) analyzed these polymorphisms in a small population of 88 Caucasian patients and 241 controls and found no significant association with PC risk. However, when the ESR 1 XbaI polymorphism was combined with the AR CAG repeat, they observed that individuals with a short $A R$ repeat $(<23)$ and ESR 1 XbaI - / - or ESR $1 X b a \mathrm{I}-/+$ had an increased PC risk. When we performed the same kind of analysis in our population, we also found a significant increased PC risk for individuals with a short $A R(<17)$ and an ESR 1 genotype 4/5, 5/6, or $6 / 6(\mathrm{OR}=$ $2.57,95 \% \mathrm{CI}=1.11-5.95, P=0.028)$. No significant association was found between the PvuII polymorphism and PC risk in another study on non-Hispanic Caucasian and African-American men including $488 \mathrm{PC}$ cases and 617 controls (29). These two ESR 1 polymorphisms were also analyzed in three populations of 260 black, 1013 non-Hispanic white and 423 Hispanic white men (30). Only in black men, XbaI polymorphism was associated with $\mathrm{PC}$ risk $(\mathrm{OR}=2.25,95 \% \mathrm{CI}=1.07-4.70$, $P=0.031)$. The limited number of studies, the small size, and the different origins of the population do not allow firm conclusions to be made regarding the real implication of these two polymorphisms. The association between the GGGA repeat from ESR 1 and PC risk seems to be the most significant. Further studies in other ethnic populations will be worthwhile to confirm our results.

Our results suggested that the role of the ESR2 gene in PC susceptibility is limited in Caucasian populations. We confirmed an association between the ESR 1 GGGA repeat and PC risk. This polymorphism seemed to be associated with a favorable Gleason score $(2-4)$ and a late onset PC, whereas the AR CAG repeat $(<17)$ was only associated with a late onset PC.

\section{Declaration of interest}

We declare that there is no conflict of interest that could be perceived as prejudicing the impartiality of the research reported.

\section{Funding}

This work was supported by the ANVAR.

\section{Acknowledgements}

The authors thank the men who volunteered to participate in the PROGENE study.

\section{References}

1 Jemal A, Siegel R, Ward E, Murray T, Xu J, Smigal C \& Thun MJ. Cancer statistics. CA: A Cancer Journal for Clinicians $2006 \mathbf{5 6}$ 106-130.

2 De Marzo AM, Nelson WG, Meeker AK \& Coffey DS. Stem cell features of benign and malignant prostate epithelial cells. Journal of Urology $19981602381-2392$.

3 Harkonen PL \& Makela SI. Role of estrogens in development of prostate cancer. Journal of Steroid Biochemistry and Molecular Biology 200492 297-305.

4 Ruizeveld De Winter JA, Janssen PJ, Sleddens HM, VerleunMooijman MC, Trapman J, Brinkmann AO, Santerse AB, Schroder FH \& Van Der Kwast TH. Androgen receptor status in localized and locally progressive hormone refractory human prostate cancer. American Journal of Pathology 1994144 735-746.

5 Bonkhoff H, Fixemer T, Hunsicker I \& Remberger K. Estrogen receptor expression in prostate cancer and premalignant prostatic lesions. American Journal of Pathology 1999155 641-647.

6 Horvath LG, Henshall SM, Lee CS, Head DR, Quinn DI, Makela S, Delprado W, Golovsky D, Brenner PC, O'Neill G, Kooner R, Stricker PD, Grygiel JJ, Gustafsson JA \& Sutherland RL. Frequent loss of estrogen receptor-beta expression in prostate cancer. Cancer Research 200161 5331-5335.

7 Latil A, Bieche I, Vidaud D, Lidereau R, Berthon P, Cussenot O \& Vidaud M. Evaluation of androgen, estrogen (ER $\alpha$ and ER $\beta$ ), and progesterone receptor expression in human prostate cancer by real-time quantitative reverse transcription-polymerase chain reaction assays. Cancer Research 200161 1919-1926.

8 Leav I, Lau KM, Adams JY, McNeal JE, Taplin ME, Wang J, Singh H \& Ho SM. Comparative studies of the estrogen receptors beta and alpha and the androgen receptor in normal human prostate glands, dysplasia, and in primary and metastatic carcinoma. American Journal of Pathology 2001159 79-92.

9 Santti R, Newbold RR, Makela S, Pylkkanen L \& McLachlan JA. Developmental estrogenization and prostatic neoplasia. Prostate 199424 67-78.

10 Prins GS, Birch L, Couse JF, Choi I, Katzenellenbogen B \& Korach KS. Estrogen imprinting of the developing prostate gland is mediated through stromal estrogen receptor alpha: studies with alphaERKO and betaERKO mice. Cancer Research 200161 6089-6097.

11 Weihua Z, Lathe R, Warner M \& Gustafsson JA. An endocrine pathway in the prostate, ER $\beta, \mathrm{AR}, 5 \alpha$-androstane- $3 \beta, 17 \beta$-diol, and CYP7B1, regulates prostate growth. PNAS 200299 $13589-13594$. 
12 Dupont S, Krust A, Gansmuller A, Dierich A, Chambon P \& Mark M. Effect of single and compound knockouts of estrogen receptors alpha $(\mathrm{ER} \alpha)$ and beta $(\mathrm{ER} \beta)$ on mouse reproductive phenotypes. Development $20001274277-4291$.

13 Cavalieri EL, Devanesan P, Bosland MC, Badawi AF \& Rogan EG. Catechol estrogen metabolites and conjugates in different regions of the prostate of Noble rats treated with 4-hydroxyestradiol: implications for estrogen-induced initiation of prostate cancer. Carcinogenesis 200223 329-333.

14 Bosland MC, Ford H \& Horton L. Induction at high incidence of ductal prostate adenocarcinomas in NBL/Cr and Sprague-Dawley Hsd:SD rats treated with a combination of testosterone and estradiol-17 beta or diethylstilbestrol. Carcinogenesis 199516 1311-1317.

15 Cancel-Tassin G, Latil A, Rousseau F, Mangin P, Bottius E, Escary JL, Berthon $\mathrm{P} \&$ Cussenot $\mathrm{O}$. Association study of polymorphisms in the human estrogen receptor alpha gene and prostate cancer risk. European Urology $2003 \mathbf{4 4} 487-490$.

16 Hakimi JM, Schoenberg MP, Rondinelli RH, Piantadosi S \& Barrack ER. Androgen receptor variants with short glutamine or glycine repeats may identify unique subpopulations of men with prostate cancer. Clinical Cancer Research 19973 1599-1608.

17 Latil AG, Azzouzi R, Cancel GS, Guillaume EC, Cochan-Priollet B, Berthon PL \& Cussenot O. Prostate carcinoma risk and allelic variants of genes involved in androgen biosynthesis and metabolism pathways. Cancer 200192 1130-1137.

18 Thellenberg-Karlsson C, Lindstrom S, Malmer B, Wiklund F, Augustsson-Balter K, Adami HO, Stattin P, Nilsson M, DahlmanWright K, Gustafsson JA \& Gronberg H. Estrogen receptor beta polymorphism is associated with prostate cancer risk. Clinical Cancer Research 200612 1936-1941.

19 Freedman ML, Pearce CL, Penney KL, Hirschhorn JN, Kolonel LN, Henderson BE \& Altshuler D. Systematic evaluation of genetic variation at the androgen receptor locus and risk of prostate cancer in a multiethnic cohort study. American Journal of Human Genetics 200576 82-90.

20 Platz EA, Leitzmann MF, Rifai N, Kantoff PW, Chen YC, Stampfer MJ, Willett WC \& Giovannucci E. Sex steroid hormones and the androgen receptor gene CAG repeat and subsequent risk of prostate cancer in the prostate-specific antigen era. Cancer Epidemiology, Biomarkers and Prevention $2005141262-1269$.

21 Simard J, Dumont M, Labuda D, Sinnett D, Meloche C, El-Alfy M, Berger L, Lees E, Labrie F \& Tavtigian SV. Prostate cancer susceptibility genes: lessons learned and challenges posed. Endocrine-Related Cancer $200310225-259$.
22 Giovannucci E, Stampfer MJ, Krithivas K, Brown M, Dahl D, Brufsky A, Talcott J, Hennekens CH \& Kantoff PW. The CAG repeat within the androgen receptor gene and its relationship to prostate cancer. PNAS 199794 3320-3323.

23 Andersson P, Varenhorst E \& Soderkvist P. Androgen receptor and vitamin D receptor gene polymorphisms and prostate cancer risk. European Journal of Cancer 200642 2833-2837.

24 Lindstrom S, Zheng SL, Wiklund F, Jonsson BA, Adami HO, Balter KA, Brookes AJ, Sun J, Chang BL, Liu W, Li G, Isaacs WB, Adolfsson J, Gronberg $\mathrm{H} \& \mathrm{Xu}$ J. Systematic replication study of reported genetic associations in prostate cancer: strong support for genetic variation in the androgen pathway. Prostate $2006 \mathbf{6 6}$ 1729-1743.

25 Forrest MS, Edwards SM, Houlston R, Kote-Jarai Z, Key T, Allen N, Knowles MA, Turner F, Ardern-Jones A, Murkin A, Williams S, Oram R, Bishop DT \& Eeles RA. Association between hormonal genetic polymorphisms and early-onset prostate cancer. Prostate Cancer and Prostatic Diseases 2005 8 95-102.

26 Zeegers MP, Kiemeney LA, Nieder AM \& Ostrer H. How strong is the association between CAG and GGN repeat length polymorphisms in the androgen receptor gene and prostate cancer risk? Cancer Epidemiology, Biomarkers and Prevention $2004 \quad 13$ 1765-1771.

27 Hardy DO, Scher HI, Bogenreider T, Sabbatini P, Zhang ZF, Nanus DM \& Catterall JF. Androgen receptor CAG repeat lengths in prostate cancer: correlation with age of onset. Journal of Clinical Endocrinology and Metabolism 199681 4400-4405.

28 Modugno F, Weissfeld JL, Trump DL, Zmuda JM, Shea P, Cauley JA \& Ferrell RE. Allelic variants of aromatase and the androgen and estrogen receptors: toward a multigenic model of prostate cancer risk. Clinical Cancer Research 20017 3092-3096.

29 Berndt SI, Chatterjee N, Huang WY, Chanock SJ, Welch R, Crawford ED \& Hayes RB. Variant in sex hormone-binding globulin gene and the risk of prostate cancer. Cancer Epidemiology, Biomarkers and Prevention 200716 165-168.

30 Hernandez J, Balic I, Johnson-Pais TL, Higgins BA, Torkko KC, Thompson IM \& Leach RJ. Association between an estrogen receptor alpha gene polymorphism and the risk of prostate cancer in black men. Journal of Urology 2006175 523-527.

Received 29 August 2008

Accepted 30 September 2008 